\title{
WORKSHOP PENERAPAN PERANGKAT PEMBELAJARAN ELEKTRONIK DI MADRASAH TSANAWIYAH NEGERI WARU SUKOHARJO
}

\section{Alfonsa Maria Sofia Hapsari \\ Tigus Juni Betri}

Pendidikan Teknologi Informasi Universitas Slamet Riyadi

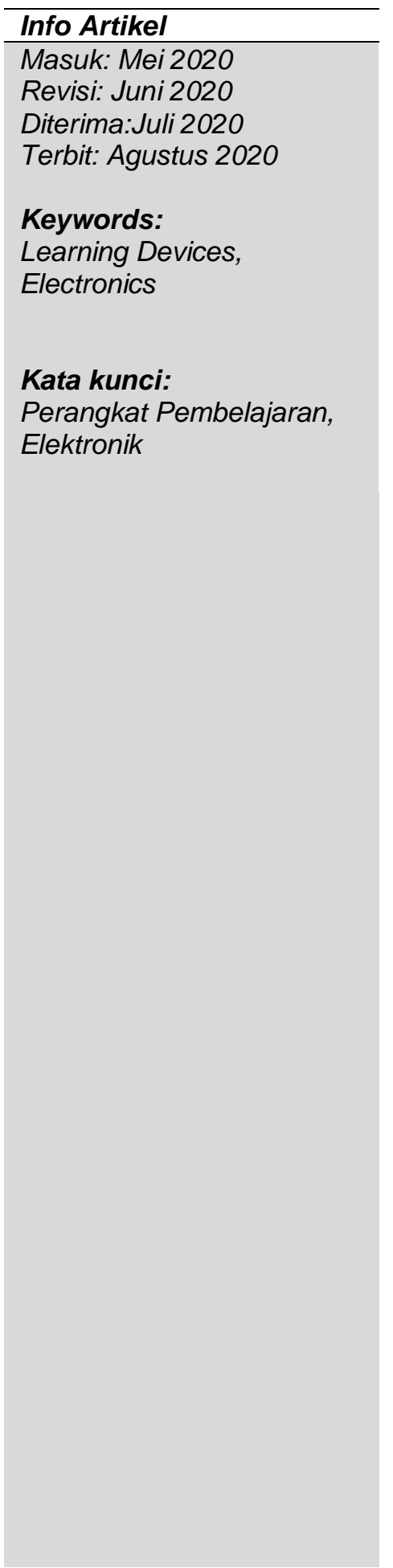

\begin{abstract}
E Learning or electronic learning is a learning concept that uses electronic media. Today almost all educational institutions use electronic learning devices in teaching and learning activities every day. However, there are still institutions that have not implemented it due to several kinds of things.

Madrasah Tsanawiyah Negeri Waru Sukoharjo as our partner in community service activities in their daily lives has had an electronic learning device but it has not been fully implemented. This is because the device is incompatible with the requirements in teaching and learning in schools.

With this community service it is hoped that it can become a new alternative for schools to implement electronic learning using electronic learning devices previously used by Slamet Riyadi University, Surakarta. Presentation activities in the form of socialization of learning tools are needed to give students an understanding of the software offered.
\end{abstract}

\section{Abstrak}

E Learning atau pembelajaran elektronik adalah konsep pembelajaran yang menggunakan media elektronik. Dewasa ini hampir semua lembaga pendidikan menggunakan perangkat pembelajaran elektronik dalam kegiatan belajar mengajar setiap harinya. Akan tetapi masih ada lembaga yang belum menerapkannya dikarenakan beberapa macam hal.

Madrasah Tsanawiyah Negeri Waru Sukoharjo sebagai mitra kami dalam kegiatan pengabdian masyarakat ini dalam kesehariannya telah memiliki perangkat pembelajaran elektronik akan tetapi belum sepenuhnya dilaksanakan. Hal ini dikarenakan tidak sesuainya perangkat tersebut dengan kebutuhan dalmam belajar mengajar di sekolah.

Dengan kegiatan pengabdian ini diharapakan dapat menjadi alternatif baru bagi sekolah untuk menerapkan pembelajaran elektronik menggunakan perangkat pembelajaran elektronik yang sebelumnya digunakan Universitas Slamet Riyadi Surakarta. Kegiatan presentasi berupa sosialisasi perangkat pembelajaran dibutuhkan untuk 
memberikan pemahaman pada siswa mengenai perangkat lunak yang ditawarkan ini.

P-ISSN: 2598-2273

E-ISSN: 2598-2281

\section{PENDAHULUAN}

Penerapan E-Learning tidak dapat dihindari dalam rangka menyambut revolusi digital 4 yang dicanangkan pemerintah. Semua institusi khususnya lembaga pendidikan dianjurkan untuk melaksanakan pembelajaran elektronik di dalam kegiatan belajar mengajar. Dalam penerapannya E -Learning mencakup kegiatan belajar mengajar secara elektronik. Fitur yang ada di dalam E-Learning mencakup tugas, kuis/ulangan, pemberian materi secara digital dan juga ujian berbasis elektronik. Pembelajaran elektronik atau biasa disebut E-Learning adalah suatu konsep atau sistem pendidikan yang menggunakan serta memanfaatkan teknologi informasi dalam proses belajar mengajar. (Ardiansyah, 2013)

Universitas Slamet Riyadi selama ini hanya menerapkan E-Learning untuk proses Kegiatan Belajar Mengajar dengan fitur-fitur standar Learning Management System. Misalnya, pemberian tugas, materi, kuis, forum dan penilaian. Madrasah Tsanawiyah Negeri Waru Sukoharjo sebagai mitra pengabdian masyarakat kami pun menerapkan pembelajaran elektronik. Dengan kegiatan pengabdian masyarakat ini diharapkan dapat memberikan alternatif pembelajaran elektronik yang baru dengan menggunakan aplikasi E-Learning di Program Studi Pendidikan Teknologi Informasi Universitas Slamet Riyadi Surakarta. Tentunya dengan mengikuti kaidah pembelajaran elektronik yang sesuai standar yang lebih baik (Candrawati, 2010)

Secara spesifik perangkat pembelajaran elektronik atau E-Learning yang kami tawarkan diharapkan dapat meningkatkan ketrampilan siswa dalam penguasaan teknologi informasi. Selain itu dengan membiasakan siswa menggunakan pembelajaran elektronik, maka siswa tidak akan kaget apabila di akhir masa sekolah mereka di Madrasah Tsanawiyah Negeri Waru Sukoharjo ini akan menghadapi ujian. Seperti yang kita tahu bahwa ujian nasional menggunakan komputer atau biasa disebut Computer Based Test. Siswa dapat mengantisipasi karena suda beradaptasi dalam waktu yang cukup lama yaitu dengan menggunakan perangkat pembelajaran elektronik ini saat masa sekolah mereka.(Granilova, 2006) 


\section{TARGET LUARAN}

Target luaran dari kegiatan pengabdian masyarakat ini adalah berupa perangkat elektronik/ E-Learning yang diharapkan dapat di terapkan di Madrasah Tsanawiyah Negeri Waru Sukoharjo. Perangkat E-Learning atau juga biasa disebut dengan Learning Management System (LMS) ini dibuat dengan menggunakan permrograman PHP dan database MySql dan diterapkan secara online dengan cara memasukkan link ke website lembaga.

\section{METODE PELAKSANAAN}

\section{Sasaran Pengabdian}

Penerapan E learning dalam pendidikan mengikutsertakan beberapa komponen. Komponen pertama adalah infrastruktur e learning. Infrastuktur berupa personal komputer, jaringan komputer, internet dan perlengkapan multimedia lainnya. Pada infrastruktur saat pembelajaran terjadi maka terkadang terjadi kendala. Kendala yang terjadi adalah tidak semua pembelajaran efektif dalam menggunakan media komputer. Banyak pembelajaran yang lebih efektif bila dilakukan secara kooperatif atau pun kolaboratif. Pada dasarnya E learning menggunakan meedia komputer untuk menyampaikan pembelajaran sedangkan salah satu teori belajar yaitu teori humanistik adalah memanusiakan manusia dan $\mathrm{E}$ learning kurang memanusiakan manusia.

Kendala lain juga muncul, yaitu ketersedian dan kelayakan infrastruktur $\mathrm{E}$ learning itu sendiri. Dalama kenyataannya tidak semua sekolah memiliki perangkat untuk menjalankan E learning begitu pula pada Perguruan Tinggi tidak semua perangkatnya layak untuk digunakan untuk proses pembelajaran $E$ learning. Kendala utamanya adalah ketika seorang pendidik menyampaikan pembelajaran melalui $\mathrm{E}$ learning maka peserta didik harus menggunakan komputer dan jaringan internet untuk menerimannya namun tidak semua peserta didik memiliki perangkat tesebut di rumahnya. Peserta didik yang tidak memiliki mendapat kendala dan harus pergi ke warnet (contohnya) untuk menggunakan E learning tersebut dan itu menambah biaya pembelajaran.

Kendala dari peserta didik yang belum dapat mengoperasikan komputer begitu juga halnya pendidik. Kita tidak bisa pungkiri pada daerah daerah tertentu $E$ learning tidak dapat diterpkan karena tidak semua daerah memiliki pembelajaran tentang $\mathrm{E}$ learning. Penggunaan E learning tidak dapat terapkan karena memang peserta didik yang belum mengetahui dan menguasai bagaimana mengoperasikan $E$ learning tersebut. Sebagian pendidik juga ada yang tidak dapat menggunakan E learning karena memang mereka tidak mendapatkan pembelajaran tersebut saat menjalani studi. Seorang guru olah raga misalnya pada saat studi mereka tidak diajarkan bagaimana menggunakan E learning secara spesifik sehingga apabila diterapkam dalam pembelajaran olah raga, guru tersebut bingun dan pembelajaran tidak dapat efektif karena tidak memiliki keahlian tersebut.

E learning memliki sistem yang dapat memvirtualisasi proses belajar mengajar mengajar konvensional. Sering disebut dengan LMS atau Learning Management System yang dimana terdapat manajemen kelas, pembuatan materi, forum diskusi dan sistem penilaian serta sistem ujian online. Pada dasarnya semua sama pada lembaga pendidikan lainnya yang dilaksanakan secara nyata namun apabila diterapkan dalam E learning akan muncul kendala lagi. Bagaimana sistem tersebut 
dapat berjalan lancar apabila tidak didukung oleh admin yang memliki kemampuan yang sesuai dengan kebutuhan tersebut. Apabila seorang admin hanya mengerti bagaimana caranya mengoperasikan sistem tersebut maka dia hanya akan mengatur softwarenya saja, lalu bagaimana sistem lainnya. Untuk itu tiap bagia seperti konten, penilaian, pembuatan soal ujian harusnya di berikan pada admin yang kompeten. $\mathrm{Hal}$ itu menjadi kendala karena kita harus melibatkan banyak orang yang memiliki kemampuan dibidangnya masing masing, sekali lagi itu memerlukan biaya yang besar dan tidak semua lembaga pendidikan dapat menjalankannya. Beberapa permasalahn kenapa belum dilaksanakan pembelajaran elektronik adalah;

a. Biaya

Banyak orang atau instansi-instansi pendidikan belum bisa menggunakan sistem pembelajaran ini karena masalah biaya. Dari membeli peralatan sampai pengoperasiannya.

b. Internet mahal

Untuk menggunakan internet masih membutuhkan biaya yang kurang bisa dijangkau oleh semua pihak.

c. Belum tersedianya hotspot di semua instansi pendidikan

Untuk alasan tertentu, seperti biaya memang belum banyak instansi-instansi pendidikan yang bisa menyediakan hotspot.

d. Belum tercukupinya media pendukung seperti PC, laptop, LCD, dll

Sarana yang dibutuhkan untuk menggunakan e-learning ini di beberapa tempat belum mencukupi sehingga menjadi kendala bagi terlaksananya e-learning di Indonesia.

e. Belum siapnya SDM yang kita miliki

SDM di sini meliputi pengajar dan siswa/mahasiswa. Masih banyak pengajar, terutama pengajar yang lama belum bisa menggunakan e-learning dalam pembelajaran karena mereka memang belum pernah mengenal apa itu e-learning dan karena sudah lamanya mereka menggunakan sistem klasik ini. Dari siswa/mahasiswanya pun masih banyak yang belum bisa menggunakan e-learning secara maksimal. Hal itu karena mereka masih menggunakan cara klasik yang diajarkan oleh guru mereka sebelumnya.

f. Sistem pendidikan yang belum berbasis e-learning

Belum banyak instansi-instansi pendidikan di Indonesia yang berbasis elearning, sehingga banyak juga yang belum bisa merasakan e-learning ini

Madrasah Tsanawiyah Negeri Waru Sukoaharjo selama ini menggunakan pembelajaran elektronik sendiri akan tetapi memang belum maksimal sehingga dengan adanya kegiatan pengabdian ini, diharap penerapan pembelajaran elektronik dapat berjalan lebih baik.

\section{METODE PENDEKATAN}

Pendekatan kegiatan pengabdian ini adalah dengan cara menawarkan alternatif perangkat pembelajaran elektronik yang baru yaitu perangkat pembelajaran elektronik yang digunakan program studi Pendidikan Teknologi Informasi. Presentasi perangkat pembelajaran elektronik terhadap siswa dan guru Madrasah Tsanawiyah Negeri Waru Sukoharjo diperlukan pada kegiatan pengabdian masyarakat ini. Hal ini 
dilakukan dengan tujuan untuk memperkenalkan metode dan fitur yang ada pada perangkat pembelajaran elektronik ini.

\section{PELAKSANAAN KEGIATAN \\ Hasil Pelaksanaan Kegiatan}

Sesuai dengan jadwal, metode dan rencana pelaksanaan program yang sudah ditentukan maka hasil yang diperoleh dalah kegiatan ini adalah sebagai berikut.

1. Peserta yang datang dan mengikuti kegiatan workshop sebanyak 15 orang dari 25 orang peserta yang diundang.

2. Komposisi peserta yang datang terdiri dari para guru di Madrasah Tsanawiyah Negeri Waru Sukoharjo

3. Berhasil dilatihkan beberapa keterampilan penggunaan aplikasi perangkat pembelajaran elektronil.

4. Peserta yang selama ini manual dalam melakukan ujian sekarang dapat menggunakan perangkat pembelajaran elektronik

5. Melalui diskusi yang dilaksanakan setelah pelatihan berlangsung menjadikan peserta paham akan hal-hal apa yang harus diperhatikan dalam penggunaan aplilkasi pembelajaran elektronik

\section{Evaluasi Hasil Pelaksaan Program}

Berdasarkan hasil evaluasi yang telah dilakukan, dapat diketahui bahwa sebagian besar peserta merasakan dampak positif dari kegiatan Tim Pengabdi. Pengetahuan untuk penerapan perangkat pembelajaran elektronil dan Sekitar $80 \%$ peserta secara aktif menanggapi positif keterampilan dan pengetahuan yang disampaikan oleh Tim Pengabdi.

\section{Kesimpulan}

Berdasarkan pengamatan terhadap proses kegiatan pengabdian masyarakat berupa pelatihan tentang penggunaan aplikasi perangkat pembelajaran elektronik untuk meningkatkan kreativitas dan life skill guru diperoleh hasil sebagai berikut.

1. Guru-guru Madrasah Tsanawiyah Negeri Waru Sukoharjo menjadi paham dan mengetahui pengoperasian perangkat pembelajaran elektronik

2. Wawasan mengenai peluang dikembangkannya media pembelajaran elektronik di kalangan para guru.

\section{Saran}

Program pengabdian mengenai workshop penerapan perangkat pembelajaran elektronik yang inovatif ini hendaknya dikembangkan pada tingkat simulasi dan uji coba di sekolah. Hal ini dimaksudkan untuk mengetahui respon pengguna (dalam hal ini sekolah, guru, dan siswa). 


\section{DAFTAR PUSTAKA}

Ardiansyah, Ivan. 2013. Eksplorasi Pola Komunikasi dalam Diskusi

Menggunakan Moddle pada Perkuliahan Simulasi Pembelajaran Kimia,

Universitas Pendidikan Indonesia, Bandung-Indonesia.

Chandrawati, Sri Rahayu. 2010. Pemanfaatan E-learning dalam Pembelajaran.

No 2 Vol. 8. http://jurnal.untan.ac.id/

L. Gavrilova, Marina. 2006. Computational Science and Its Applications - ICCSA 2006: 6th International Conference. Glasgow, UK: Springer. 